\title{
Lipid and Yield Evaluation in Salicornia bigelovii by the Influence of Chitosan-IBA, in Conditions of the Sonora Desert
}

\author{
Gerardo Zapata-Sifuentes ${ }^{1,2}$, Pablo Preciado-Rangel ${ }^{1,2}{ }^{\mathbb{D}}$, Reyna Roxana Guillén-Enríquez ${ }^{1}$, \\ Francisca Sánchez Bernal ${ }^{2}$, Ramon Jaime Holguin-Peña ${ }^{3}$, Carlos Borbón-Morales ${ }^{4}$ and \\ Edgar Omar Rueda-Puente ${ }^{5, *}$ (1)
}

Citation: Zapata-Sifuentes, G.; Preciado-Rangel, P.; Guillén-Enríquez, R.R.; Bernal, F.S.; Holguin-Peña, R.J.; Borbón-Morales, C.; Rueda-Puente, E.O. Lipid and Yield Evaluation in Salicornia bigelovii by the Influence of Chitosan-IBA, in Conditions of the Sonora Desert. Agronomy 2021, 11, 428. https://doi.org/10.3390/ agronomy11030428

Academic Editors: José M. De la Rosa and Marina Paneque

Received: 2 February 2021

Accepted: 23 February 2021

Published: 26 February 2021

Publisher's Note: MDPI stays neutral with regard to jurisdictional claims in published maps and institutional affiliations.

Copyright: (C) 2021 by the authors Licensee MDPI, Basel, Switzerland. This article is an open access article distributed under the terms and conditions of the Creative Commons Attribution (CC BY) license (https:/ / creativecommons.org/licenses/by/ $4.0 /)$.
1 Campus Instituto Tecnológico de Torreón, Tecnológico Nacional de México, Antigua Carretera Torreón-San Pedro km 7.5, 27170 Torreón, Coahuila, Mexico; gdo.zapata81@gmail.com (G.Z.-S.); ppreciador@yahoo.com.mx (P.P.-R.); reguillen@outlook.com (R.R.G.-E.)

2 Unidad Laguna, Universidad Autónoma Agraria Antonio Narro, Periférico Raúl López Sánchez s/n, Colonia Valle Verde, 27054 Torreón, Coahuila, Mexico; francis_sanchezb@hotmail.com

3 Centro de Investigaciones Biológicas del Noroeste, Mar Bermejo No. 195, Col. Playa Palo Santa Rita, 23090 La Paz, Baja California Sur, Mexico; jholguin04@cibnor.mx

4 Departamento de Economía, Centro de Investigación en Alimentación y Desarrollo A.C., Carretera a la Victoria Km. 0.6, 83304 Hermosillo, Sonora, Mexico; cborbon@ciad.mx

5 Departamento de Agricultura y Ganadería, Universidad de Sonora, Bulevard Luis Encinas y Rosales s/n, Colonia Centro, 83000 Hermosillo, Sonora, Mexico

* Correspondence: erueda04@santana.uson.mx; Tel.: +52-1-641-327-0764

Abstract: The present investigation aimed to evaluate the effect of Chitosan-Indole Butyric Acid (IBA) in the seed of Salicornia bigelovii under field conditions in Sonora, Mexico. During two vegetative cycles (2018/2019-2019/2020), cuttings of S. bigelovii were treated with 100 and 50\% Chitosan from shrimp exoskeletons and indole butyric acid at 0.937 and $1.25 \mathrm{~g} \cdot \mathrm{kg}^{-1}$ and placed in basins under conditions of the Sonora desert, Mexico. Variables were measured: seed production, physicochemical analysis and lipid profile of the seed. The results affected significant increases $(p<0.05)$ in the evaluated variables, highlighting the treatment based on Chitosan $100 \%$ IBA $0.937 \mathrm{~g} \cdot \mathrm{kg}^{-1}$. The results based on chitosan and IBA in cuttings, are a biostimulant in the morpho-physiology, yield production, and lipid content of S. bigelovii. Large-scale studies as a production system should be considered in further studies.

Keywords: fatty acids; seed; halophytes; growth promoters; cuttings; biostimulant

\section{Introduction}

Salicornia bigelovii Torr. is a native plant of the Sonora Desert, it belongs to the group of halophytes [1]. Its life cycle ranges between 9 and 11 months, its height ranges between $35-50 \mathrm{~cm}$, it has ramifications that give the appearance of a "candelabrum", the fruit of Salicornia is a pubescent (hairy) angular seed of $1-1.5 \mathrm{~mm}$ long. The seeds of S. bigelovii are found in the terminal spike formed by the stems and leaves.

Over the years, Salicornia has been a plant of great interest to different cultures, including France and England, where its gastronomy includes its consumptions. In Mexico, Salicornia is native to the state of Sonora, where it is mainly associated with hot and dry weather and the prevalence of saline soils [1]. Among its main applications are: human food, soap production, glass, medicinal, forage for animal consumption, biofuels, among others [2].

Halophyte $S$. bigelovii is a plant rich in lipids, highlighting palmitic acid $(6.9 \%)$, stearic $45(2.3 \%)$, oleic $(14.1 \%)$, linoleic $(73.1 \%)$, linoleic $(2.4 \%)$ and others $(1.2 \%)[3,4]$. The above suggests an interesting source for the production of edible oils or biodiesel, as well as to obtain by-products such as flour with high protein content (for food supplement for live-stock, fish and shrimp) after having processed the halophyte. In previous studies, 
the determination of the yield and analysis of the Salicornia seeds has been analyzed [5], finding that the values for the oil of the halophyte seed are higher than those of some seeds used in the industry to obtain oils and fats, such as soybeans and cotton. Likewise, it has been reported that the oil content of S. bigelovii is much higher in seeds harvested in coastal environments implemented with fertilizer, which is attributed to the salt tolerance of these halophytes and the availability of urea and ammonium nitrate and the seasonal behavior in the crop.

An adverse factor that influences the establishment of the culture is the ecophysiological characteristics itself, as well as the techniques used in the cultivation of this halophyte, which affects the yield of oil obtained from S. bigelovii [3]. The latter has promoted the study and evaluation of modalities that positively influence its incorporation as a crop. In this regard, studies show that it is feasible to achieve the propagation of Salicornia through techniques such as cuttings, using chitosan of marine origin as a growth promoter [6]. Similarly, studies have been developed where the plant-microorganism interaction is analyzed [7], however, there is still some controversy about its results at productive levels, which encourages the continued evaluation of the effect of novo biofertilizers of natural origin such as chitosan, which is proposed in the present study and could be a favorable alternative to increase the lipid capacity of the halophyte seed.

At an industrial level, chitosan is obtained mainly from chitin obtained from crustacean sources such as shrimp and crab, although it is also possible to obtain it from crabs and squid feathers as well as from fungi and insects [8-13]. This biopolymer has been widely used in agriculture in crops such as corn [14], tobacco [15], rice [16], orchid [17], improving the seed germination process, crop yields and adsorption of micro-nutrients from different crops and stimulating the defense mechanism of plants and the formation of physical barriers $[18,19]$. Studies related to chitosan and the culture of S. bigelovii are reduced to that of López-Corona et al. [6], which is aimed at vegetative levels, so the present study led to evaluate it and know the effect on the performance and lipid properties of the $S$. bigelovii seed and thus propose chitosan as a viable and effective source in the increase and quality of oils, making it more attractive for various sectors, by increasing its value and profitability.

\section{Materials and Methods}

The experimental process was developed in Northwestern Mexico between the parallels $28^{\circ} 22^{\prime}$ and $29^{\circ} 05^{\prime}$ of the north latitude and the meridians $111^{\circ}$ and $112^{\circ} 25^{\prime}$ of west longitude with an average altitude of $70 \mathrm{~m}$ above sea level. The semi desert has a climate in summer with high average temperatures ranging between 48 to $54{ }^{\circ} \mathrm{C}$ and in winter with minimums of $0{ }^{\circ} \mathrm{C}$, and a relative humidity between 15 and $25 \%$.

\subsection{Obtaining Chitosan and Preparation of Indole Butyric Acid-IBA-}

Shrimp exoskeletons obtained in processing industries were used for the extraction of chitosan, which were reduced to a particle size when using a sieve smaller than $250 \mu \mathrm{m}$. For this process, the methodology proposed by Hernández Cocoletzi et al. [20] was carried out.

The process was carried out in different stages in which the chitin was first extracted and then the chitosan (QUI) was obtained. The chemical method was used, where $\mathrm{HCl}$ and $\mathrm{NaOH}$ solutions were used in order to remove lipids, minerals, pigments and proteins bound to chitin [20]. The QUI concentrations used in the treatments were $50 \%$ and $100 \%$ $(w / v)$, and to know these percentages firstly the overall yield (RG) of the QUI extraction process in the exoskeletons was obtained using the following expression: $R G=R R / R T$ $\times 100$ where: RR: real yield, amount in grams of the final product (QUI); RT: theoretical yield, quantity in grams of the sample with which the process was started. From $154.63 \mathrm{~g}$ of shrimp exoskeleton sample and after the process previously mentioned, $81.22 \mathrm{~g}$ was obtained of dry QUI as final product and considered as a $100 \%$; to obtain the other treatment, the QUI as a final product, was reduced at $50 \%$ for which a $2 \%(v / v)$ acetic acid solution 
was used. Carrying out the dissolution at a temperature of $60{ }^{\circ} \mathrm{C}$ with constant magnetic stirring, they were subsequently filtered to discard impurities in the solution [6,21-23].

According to the preparation of the IBA, a solid commercial product was used (RADIX $\left.{ }^{\circledR} 10,000\right)$. The IBA was prepared, placing 0.937 and $1.25 \mathrm{mg}$ in $1 \mathrm{~g}$ of inert and odorless agricultural talc (hydrated magnesium silicate), respectively. Later, it was mixed with a domestic mixer to homogenizer and to proceed to treat the cuttings. These concentrations were selected, according to the results obtained for IBA in previous studies using woody species [24].

\subsection{Treatment of Cuttings}

A completely randomized design with nine treatments was used, as seen in (Table 1), each treatment contained 12 repetitions. Cuttings were used, which were obtained from vegetative stems ( $1 \mathrm{~cm}$ in diameter and $25 \mathrm{~cm}$ in length) of the middle part of S. bigelovii plants, collected from Bahía de Kino, Sonora (Lat. 29 $9^{\prime} 26.62^{\prime \prime} \mathrm{N}$ and Long. $112^{\circ} 14^{\prime} 40.66^{\prime \prime} \mathrm{W}$ ), in flowering stage (eight months after emergence). The study was carried out in two different cycles (2018-2019 and 2019-2020) with plant cuttings. Each cutting obtained had a cross-shaped cut at the base and it was submerged in each treatment based on chitosan (QUI) and/or IBA for $15 \mathrm{~min}$.

Table 1. Treatments based on Chitosan bioproduct of marine origin (QUI) and indole butyric acid (IBA) in conditions of the Altar desert, Sonora.

\begin{tabular}{cc}
\hline & Treatments \\
\hline QUI $50 \%$ & QUI $50 \%+$ IBA $0.937 \mathrm{~g} \cdot \mathrm{kg}^{-1}$ \\
QUI $100 \%$ & QUI $50 \%+$ IBA $1.25 \mathrm{~g} \cdot \mathrm{kg}^{-1}$ \\
IBA $0.937 \mathrm{~g} \cdot \mathrm{kg}^{-1}$ & QUI $100 \%+$ IBA $0.937 \mathrm{~g} \cdot \mathrm{kg}^{-1}$ \\
IBA $1.25 \mathrm{~g} \cdot \mathrm{kg}^{-1}$ & QUI $100 \%+$ IBA $1.25 \mathrm{~g} \cdot \mathrm{kg}^{-1}$ \\
& Control (Irrigation drinking water) \\
\hline
\end{tabular}

\subsection{Transplanting Cuttings in Micro-Basins}

Cuttings obtained from the $S$. bigelovii plant were first placed in black polyethylene bags, which were $30 \mathrm{~cm}$ high and $20 \mathrm{~cm}$ in diameter. Then, sand was sieved in a sieve with a $1 \mathrm{~mm}$ mesh opening, which was used as a substrate for 30 days, a process that allowed for a "softening of bark = pre-rooting" for each treatment with QUI and IBA (Table 1$)$. This pre-rooting was conducted under nursery conditions $(>90 \% \mathrm{RH}$ and at $27 \pm 2{ }^{\circ} \mathrm{C}$ ). After 30 days, the cuttings were treated again (according to their treatment), and then they were located in micro-basins under field conditions. The conditions $\left(\mathrm{T}^{\circ} \mathrm{C}\right.$, $\mathrm{RH}$, photosynthetically active radiation (Par: $\mathrm{me}^{-2} \mathrm{~s}^{-1}$ ), and average annual insolation (Aai h)) that prevailed in the field are indicated in Table 2.

Table 2. Present conditions in the different phenological stages of S. bigelovii seed production from cuttings.

\begin{tabular}{|c|c|c|c|c|}
\hline Phenological Stage/1st Experiment & $\mathbf{T}^{\circ} \mathbf{C}$ & $\begin{array}{l}\mathrm{RH} \\
(\%)\end{array}$ & $\begin{array}{c}\text { Par } \\
\left(\mathrm{me} \mathrm{m}^{-2} \mathrm{~s}^{-1}\right)\end{array}$ & $\underset{\mathrm{h}}{\mathrm{Aai}}$ \\
\hline Collection of cuttings and rooting (Nov/2018) & $39 \pm 2$ & $<45$ & 510.33 & 8 \\
\hline Pre-flowering (Dec/2018-Feb/2019) & $30 \pm 4$ & $<35$ & 485.22 & 7 \\
\hline Flowering (March-April/2019) & $38 \pm 3$ & $<15$ & 580.32 & 10 \\
\hline $\begin{array}{l}\text { Physiological maturity (seed production) } \\
\text { (May-July/2019) }\end{array}$ & $48 \pm 4$ & $<10$ & 589.43 & 11 \\
\hline \multicolumn{5}{|l|}{ Phenological stage/2nd experiment } \\
\hline Rooting (Oct/2019) & $48 \pm 3$ & $<45$ & 550.12 & 9 \\
\hline Pre-flowering (Nov/2019-Jan/2020) & $30 \pm 4$ & $<35$ & 495.22 & 8 \\
\hline Flowering (Feb-March/2020) & $38 \pm 3$ & $<15$ & 560.12 & 8 \\
\hline Physiological maturity (seed production) (April-June/2020) & $45 \pm 4$ & $<10$ & 576.43 & 11 \\
\hline
\end{tabular}

Temperature $(\mathrm{T}){ }^{\circ} \mathrm{C}$; Photosynthetically active radiation (Par: me $\mathrm{m}^{-2} \mathrm{~s}^{-1}$ ); Average annual insolation (Aai h.day). 
Basins of $7 \mathrm{~m}$ long and $1.5 \mathrm{~m}$ wide were used; the cuttings were located at an approximate distance of $0.27 \mathrm{~m}$ between cuttings, considering a row, with 45 cuttings per treatment, yielding a total of 405 experimental units in each one from the two production cycles. Prior to transplantation, an analysis was carried out on the substrate to determine the content of organic matter (O.M.), macro and micronutrients, as well as the $\mathrm{pH}$ of the soil (Table 3).

Table 3. Physical and chemical parameters of the substrate in the experimental basins under conditions of the Altar desert, Sonora.

\begin{tabular}{ccccccccccc}
\hline Texture & $\mathbf{p H}$ & $\begin{array}{c}\mathrm{CE} \\
\mathrm{dS} \cdot \mathbf{m}\end{array}$ & $\begin{array}{c}\text { O.M. } \\
\%\end{array}$ & SAR & $\begin{array}{c}\mathrm{NO}_{\mathbf{3}} \\
\mathbf{m g} \cdot \mathbf{k g}^{-\mathbf{1}}\end{array}$ & $\begin{array}{c}\mathbf{N O}_{\mathbf{2}} \\
\mathbf{m g} \cdot \mathbf{k g}^{-\mathbf{1}}\end{array}$ & $\begin{array}{c}\mathrm{Ca} \\
\mathbf{m g} \cdot \mathbf{k g}^{-\mathbf{1}}\end{array}$ & $\begin{array}{c}\mathbf{M g} \\
\mathbf{m g} \cdot \mathbf{k g} \mathbf{- 1}^{-\mathbf{1}}\end{array}$ & $\begin{array}{c}\mathrm{K} \\
\mathbf{g} \cdot \mathbf{L}^{-\mathbf{1}}\end{array}$ & $\begin{array}{c}\mathbf{N a} \\
\mathbf{g} \cdot \mathbf{L}^{-\mathbf{1}}\end{array}$ \\
\hline Sandy & 7.0 & 2.5 & 0.02 & 8.82 & 0.09 & 0.01 & 5.80 & 19.36 & 0.1 & 1.6 \\
\hline
\end{tabular}

O.M: organic matter; CE: electric conductivity; SAR: sodium absorption ratio.

The irrigation used in the first stage $=$ rooting $=($ during the 30 days after transplantation (dat)) was the daily waterlogging $\left(47 \mathrm{~L} \cdot \mathrm{m}^{-2}\right)$. Subsequently, alternate watering (every third day), by means of a system of micro-sprinkling was used for 190 days, after waterlogging (daw); the remaining 20 days were reduced to once a week $\left(47 \mathrm{~L} \cdot \mathrm{m}^{2}\right)$ and 20 without irrigation application.

\subsection{Variables Evaluated. Root Length (cm), Fresh and Dry Root Weight (Root g/Plant), and} Number and Length of Shoots per Cutting $(\mathrm{cm})$

The variables evaluated were final root length, fresh and dry root weight, the number and length of shoots per cutting. For the final root length 10 plants at 180 days were selected in each of the vegetative cycles; after the plants were obtained and washed in the laboratory, the root was determined after sectioning and was measured using a vernier and a millimeter ruler. The fresh weight of the root was sectioning aerial part of the cuttings from the base of the stem. The dry weight was obtained after dehydrating the roots at $80^{\circ} \mathrm{C}$ in an oven (Shel Lab model $1380 \mathrm{FM}$ ). The values reflected in the results of these variables are the average of both production cycles. For its part, the number of shoots per cutting was counted and the length of the shoots was measured in each treatment by means of a millimeter rule of the second third (central part) of the plant; this variable was carried out 180 dat.

\subsection{Nitrates in Sap}

In the phenological state of flowering, the content of nitrates in sap $\left(\mathrm{N}-\mathrm{NO}_{3} \mathrm{mg} \cdot \mathrm{mL}^{-1}\right.$ of sap) was obtained using the Coombs [25] technique and analyzed according to Wood [26].

\subsection{Seed Production}

Seed production was evaluated considering end life time of each treatment; 10 plants were randomly selected to which the variable seed production per plant $\left(\mathrm{g} \cdot\right.$ plant $\left.^{-1}\right)$ was quantified, where the value was determined by multiplying the average obtained of seed production per plant, by the total number of plants that they were transplanted in basins [27]. Subsequently, the dry matter produced by micro basin was evaluated (dry matter in $\mathrm{g} \cdot \mathrm{m}^{-2}$ ). The values reflected in the results are the average of both production cycles.

\subsection{Physicochemical Analysis of the Seed (Ash, Protein and Lipid Ratios of the S. bigelovii Seed)}

The variables of protein, moisture, ash and total lipids were quantified in the seed samples produced in each of the treatments. The technique to obtain proteins was developed by the Microkjeldajl method; for ash due to weight difference, calcining the sample at $500{ }^{\circ} \mathrm{C}$ for $24 \mathrm{~h}$. Within the total lipid variable, the absolute percentage of fatty acids (palmitic, stearic, oleic, linoleic and linolenic) was obtained, applying the technique suggested by Arredondo et al. [28] for these analyzes. For the corresponding derivation of fatty acids, 
the technique of Sato and Murata [29] was applied. The values reflected in the results are the average of both production cycles.

\subsection{Statistical Analysis}

An analysis of variance of the variables evaluated in the two established cycles and the multiple comparison of means was performed using the Tukey test (between cycles (2018-2019/2019-2020), between treatments and year $\times$ treatments) one-way, with a level $95 \%$ significance. All analyzes were performed using the SAS statistical package.

\section{Results}

\subsection{Root Length}

The results on the length of the roots are observed in Table 4, being able to appreciate that in between vegetative cycles (2018-2019/2019-2020) and between treatments there were significant meanings with $(p<0.05)$, the opposite occurred in year $\times$ treatments. Root development behavior showed that, 30 days after pre-rooting, none of the cuttings showed root development in all treatments. The presence of roots in both vegetative cycles based on cuttings, was evidenced $(p<0.05)$ in the treatments with Chitosan (QUI) $50 \%$ in its presentations with IBA at a rate of 0.937 and $1.25 \mathrm{~g} \cdot \mathrm{kg}^{-1}$ at $60 \mathrm{dat}$ ); although, in the experimental units of the control (treatment with water) there was also root development, these were 300\% exceeded by the previously mentioned treatments (QUI 50\% + IBA at a rate of 0.937 and $\left.1.25 \mathrm{~g} \cdot \mathrm{kg}^{-1}\right)$. A similar behavior was witnessed in the subsequent evaluation days (90, 120, 150 and 180 dat, in both vegetative cycles (2018/2019 and 2019-2020). In the last evaluation of root length (180 dat), the treatments showed a significant difference vs. the control treatment (Table 4), with those based on QUI at 50 and $100 \%+$ IBA $0.937 \mathrm{~g} \cdot \mathrm{kg}^{-1}$ appearing in the first place. For its part, the control obtained the significantly lower values of root development (around 39\% lower in relation to the highest value obtained).

Table 4. Mean values of root length (dat), fresh and dry root weight in cuttings of S. bigelovii treated with Chitosan (QUI) and Indole butyric acid (IBA) from two phenological cycles under conditions in the Altar desert, Sonora.

\begin{tabular}{|c|c|c|c|c|c|c|c|c|}
\hline \multirow{2}{*}{ Treatment } & \multirow[b]{2}{*}{ dat 30} & \multicolumn{5}{|c|}{ Root length (cm) } & \multirow{2}{*}{$\begin{array}{l}\text { Fresh Weight } \\
\text { (g.root/plant) }\end{array}$} & \multirow{2}{*}{$\begin{array}{c}\text { Dry Weight } \\
\text { (mg·root/plant) }\end{array}$} \\
\hline & & dat 60 & dat 90 & dat 120 & dat 150 & dat 180 & & \\
\hline QUI 50\% & 0 & $13.9 \pm 0.8$ & $13.2 \pm 1.9$ & $27.2 \pm 2.6$ & $30.1 \pm 2.7$ & $42.2 \pm 2.9 \mathrm{ab}$ & $358.09 \pm 12.02 \mathrm{ab}$ & $89.9 \pm 12.18 \mathrm{ab}$ \\
\hline QUI 100\% & 0 & $14.3 \pm 0.6$ & $14.6 \pm 2.1$ & $26.7 \pm 2.8$ & $30.1 \pm 2.0$ & $45.3 \pm 2.8 \mathrm{a}$ & $361.11 \pm 10.21 \mathrm{a}$ & $90.2 \pm 9.33 \mathrm{ab}$ \\
\hline IBA $0.937 \mathrm{~g} \cdot \mathrm{kg}^{-1}$ & 0 & $10.9 \pm 0.4$ & $13.3 \pm 0.7$ & $25.9 \pm 1.8$ & $30.6 \pm 2.9$ & $41.4 \pm 2.3 \mathrm{ab}$ & $311.3 \pm 11.09 c$ & $88.8 \pm 8.08 \mathrm{~b}$ \\
\hline IBA $1.25 \mathrm{~g} \cdot \mathrm{kg}^{-1}$ & 0 & $10.7 \pm 0.3$ & $14.3 \pm 1.3$ & $26.1 \pm 1.8$ & $30.3 \pm 2.6$ & $40.4 \pm 2.5 \mathrm{ab}$ & $362.6 \pm 9.11 \mathrm{a}$ & $90.60 \pm 11.18 \mathrm{ab}$ \\
\hline QUI $50 \%$ + IBA $0.937 \mathrm{~g} \cdot \mathrm{kg}^{-1}$ & 0 & $16.1 \pm 0.4$ & $14.2 \pm 2.1$ & $26.7 \pm 2.3$ & $32.8 \pm 2.8$ & $47.4 \pm 2.9 \mathrm{a}$ & $362.7 \pm 7.28 \mathrm{a}$ & $90.65 \pm 9.11 \mathrm{ab}$ \\
\hline QUI $50 \%$ + IBA $1.25 \mathrm{~g} \cdot \mathrm{kg}^{-1}$ & 0 & $16.0 \pm 0.9$ & $13.2 \pm 1.8$ & $26.2 \pm 2.1$ & $39.2 \pm 3.1$ & $44.3 \pm 2.1 \mathrm{a}$ & $356.7 \pm 11.33 \mathrm{ab}$ & $88.93 \pm 6.98 \mathrm{ab}$ \\
\hline QUI $100 \%$ + IBA $0.937 \mathrm{~g} \cdot \mathrm{kg}^{-1}$ & 0 & $12.2 \pm 1.1$ & $13.0 \pm 1.2$ & $27.1 \pm 2.8$ & $31.2 \pm 1.8$ & $47.8 \pm 2.6 \mathrm{a}$ & $366.7 \pm 7.21 \mathrm{a}$ & $91.0 \pm 7.45 \mathrm{ab}$ \\
\hline QUI $100 \%+$ IBA $1.25 \mathrm{~g} \cdot \mathrm{kg}^{-1}$ & 0 & $9.0 \pm 0.5$ & $12.9 \pm 0.8$ & $25.9 \pm 1.3$ & $39.9 \pm 1.9$ & $45.4 \pm 2.1 \mathrm{a}$ & $291.1 \pm 5.87 \mathrm{~d}$ & $81.4 \pm 12.01 b$ \\
\hline Control & 0 & $4.0 \pm 1.5$ & $10.8 \pm 0.2$ & $21.9 \pm 0.4$ & $32.3 \pm 1.2$ & $34 \pm 3.9 c$ & $271.7 \pm 8.80 \mathrm{e}$ & $112.3 \pm 9.37 \mathrm{a}$ \\
\hline
\end{tabular}

The letters on the day 180, have indicated statistically similar with $p<0.05$; dat = days after transplantation.

\subsection{Fresh and Dry Root Weight in S. bigelovii Cuttings}

Results of fresh weight of the root system indicate that between cycles (2018-2019/ 2019-2020) and between treatments were significant, while in the interaction of cycle $\times$ treatments it was the adverse (Table 4); it can be seen that at 180 dat, in the fresh weight of the root system there were significant differences between the treatments $(p<0.05)$, with the lowest values the control and the treatment (QUI $100 \%+$ IBA $1.25 \mathrm{~g} \cdot \mathrm{kg}^{-1}$ and the IBA at $0.937 \mathrm{~g} \cdot \mathrm{kg}^{-1}$ ).

It should be revealed that, in the 2018/19 cycle, compared to 2019/20, the numerical behaviors differed between treatments, with the control having the lowest values (30 and $20 \%$ lower vs. the superior treatment of QUI $100 \%+$ IBA $0.937 \mathrm{~g} \cdot \mathrm{kg}^{-1}$, respectively). A similar behavior was conceived in dry weight in relation to fresh weight (significance be-tween cycles (2018-2019/2019-2020) and between treatments; the opposite in the interaction of cycle $\times$ treatments), but with the particularity that the superior treatment was the Control 
in both cycles $(p<0.05)$ (Table 4$)$; the lowest values obtained were in the QUI $50 \%$ and the QUI $100 \%$ + IBA $1.25 \mathrm{~g} \cdot \mathrm{kg}^{-1}$ treatments (88.8 and $81.4 \mathrm{mg}$ root/plant, respectively).

\subsection{Number and Length of New Shoots in S. bigelovii Cuttings}

No significant differences were observed with $p<0.05$, in the number of shoots developed in the cuttings subjected to different treatments (Table 5) per cycle and between treatments and cycle $\times$ treatment, however numerically it can be seen that the superior treatment was that of QUI $50 \%+$ IBA $0.937 \mathrm{~g} \cdot \mathrm{kg}^{-1}$. It can be seen that in the length of shoots there was significance with $p<0.05$ between cycles (2018-2019/2019-2020); between treatments and year $\times$ treatments. In the first cycle (2018/2019), the treatments based on QUI and IBA in their various formulations significantly surpassed the control, values above the latter, by $69 \%$ by the QUI $100 \%$ and the QUI $50 \%+$ IBA $0.937 \mathrm{~g} \cdot \mathrm{kg}^{-1}$. Regarding the number of outbreaks, there were no significant differences between treatments, it was even possible to see that the control numerically surpassed the treatments based on QUI 50\% and QUI $100 \%+$ IBA $0.937 \mathrm{~g} \cdot \mathrm{kg}^{-1}$. A similar behavior between treatments was observed in the second 2019/2020 cycle in both variables (length and number of shoots), showing that, numerically, the second period 2019/2020 was superior. Likewise, the 50\% QUI and 100\% QUI + IBA $0.937 \mathrm{~g} \cdot \mathrm{kg}^{-1}$ treatments turned out to be the most affected in these variables.

Table 5. Root length, fresh and dry root weight, and number and length of shoots generated from cuttings of $S$. bigelovii, produced in the Altar desert, Sonora.

\begin{tabular}{|c|c|c|c|c|c|c|}
\hline \multirow{3}{*}{ Treatment } & \multicolumn{2}{|c|}{$\begin{array}{c}\text { Shoot } \\
\text { 1st Cycle }\end{array}$} & \multicolumn{2}{|c|}{$\begin{array}{c}\text { Shoot } \\
\text { 2nd Cycle }\end{array}$} & \multirow{2}{*}{\multicolumn{2}{|c|}{$\begin{array}{c}\text { Nitrates in Sap } \\
\mathrm{N}-\mathrm{NO}_{3} \mathrm{mg} \cdot \mathrm{mL}^{-1}\end{array}$}} \\
\hline & \multirow[t]{2}{*}{ Long (cm) } & \multirow[t]{2}{*}{ Number } & \multirow[t]{2}{*}{ Long (cm) } & \multirow[t]{2}{*}{ Number } & & \\
\hline & & & & & 1st Cycle & 2nd Cycle \\
\hline QUI 50\% & $17.28 \pm 1.7 \mathrm{~b}$ & $17 \pm 3 \mathrm{a}$ & $19.31 \pm 1.6 \mathrm{ab}$ & $18 \pm 3 a$ & $498.91 \pm 47 \mathrm{ab}$ & $477.31 \pm 38 \mathrm{ab}$ \\
\hline QUI $100 \%$ & $22.50 \pm 1.9 \mathrm{a}$ & $22 \pm 3 \mathrm{a}$ & $24.76 \pm 1.8 \mathrm{a}$ & $20 \pm 4 \mathrm{a}$ & $511.9 \pm 33 \mathrm{a}$ & $521.84 \pm 31 \mathrm{a}$ \\
\hline IBA $0.937 \mathrm{~g} \cdot \mathrm{kg}^{-1}$ & $10.29 \pm 1.7 \mathrm{~d}$ & $18 \pm 2 a$ & $19.11 \pm 1.9 \mathrm{ab}$ & $20 \pm 4$ a & $502.11 \pm 39 \mathrm{a}$ & $532.79 \pm 32 \mathrm{a}$ \\
\hline IBA $1.25 \mathrm{~g} \cdot \mathrm{kg}^{-1}$ & $21.50 \pm 1.5 \mathrm{a}$ & $23 \pm 3 a$ & $23.11 \pm 1.7 \mathrm{a}$ & $23 \pm 3 a$ & $498.77 \pm 39 \mathrm{ab}$ & $509.11 \pm 23 \mathrm{a}$ \\
\hline QUI $50 \%+$ IBA $0.937 \mathrm{~g} \cdot \mathrm{kg}^{-1}$ & $22.52 \pm 1.9 \mathrm{a}$ & $22 \pm 3 a$ & $24.42 \pm 2.9 \mathrm{a}$ & $25 \pm 2 \mathrm{a}$ & $505.81 \pm 15 \mathrm{a}$ & $512.33 \pm 21 \mathrm{a}$ \\
\hline QUI $50 \%+$ IBA $1.25 \mathrm{~g} \cdot \mathrm{kg}^{-1}$ & $19.38 \pm 1.8 b$ & $21 \pm 2 \mathrm{a}$ & $21.12 \pm 1.8 \mathrm{a}$ & $23 \pm 3 a$ & $525.13 \pm 24 a$ & $523.02 \pm 21 \mathrm{a}$ \\
\hline QUI $100 \%+$ IBA $0.937 \mathrm{~g} \cdot \mathrm{kg}^{-1}$ & $21.58 \pm 1.5 \mathrm{a}$ & $16 \pm 4 \mathrm{a}$ & $23.18 \pm 2.7 \mathrm{a}$ & $19 \pm 4 \mathrm{a}$ & $587.29 \pm 33 \mathrm{a}$ & $543.65 \pm 29 a$ \\
\hline QUI $100 \%+$ IBA $1.25 \mathrm{~g} \cdot \mathrm{kg}^{-1}$ & $14.93 \pm 1.7 \mathrm{c}$ & $17 \pm 3 \mathrm{a}$ & $21.11 \pm 1.5 \mathrm{ab}$ & $17 \pm 4 \mathrm{a}$ & $565.33 \pm 31 \mathrm{a}$ & $577.08 \pm 29 a$ \\
\hline Control & $9.37 \pm 1.9 \mathrm{~d}$ & $18 \pm 2 \mathrm{a}$ & $14.43 \pm 1.9 \mathrm{c}$ & $20 \pm 3 a$ & $334.17 \pm 29 c$ & $421.11 \pm 16 b c$ \\
\hline
\end{tabular}

Values with equal letters within each column are not statistically similar $(p>0.05)$. dat $=$ days after transplantation. QUI $=$ Chitosan.

\subsection{Nitrates in Sap}

The results show that there were significant differences between treatments based on QUI and IBA in their different forms evaluated in the present study (Table 5), however, it was observed in the variance analyzes that between cycles (2018-2019/2019-2020) and year $\times$ treatments there was no significance; between treatments it was observed that in comparison with the control the values were significant. In both vegetative cycles, the control behaved with lower values than the other treatments. Between cycles there were no significant differences in the production of nitrates from sap. However, the treatment that stands out in this variable are those mixtures based on $100 \%$ QUI + IBA at 0.937 and $1.25 \mathrm{~g} \cdot \mathrm{kg}^{-1}$.

\subsection{Seed Production}

The results obtained for the seed production variable (Table 6) show that the plants treated with QUI $100 \%+$ IBA $0.937 \mathrm{~g} \cdot \mathrm{kg}^{-1}$ produced a greater quantity of seeds with $p<0.05$ $\left(1.56 \mathrm{~g} \cdot\right.$ plant $\left.^{-1}\right)$, followed by the concentrations of QUI $50 \%+$ IBA $0.937 \mathrm{~g} \cdot \mathrm{kg}^{-1}$ and QUI $50 \%(1.56,1.55$ and 1.52 , respectively); the lower values were obtained in those treatments based on IBA $0.937 \mathrm{~g} \cdot \mathrm{kg}^{-1}$ and the one named as control with 0.55 and $0.54 \mathrm{~g} \cdot$ plant $^{-1}$; 
the results did not vary between cycles (2018/2019 and 2019/2020) in addition to the significance of year $\times$ treatments being null. Notwithstanding the above, these results of $g$ per plant were significantly reflected in the variables of $\mathrm{g} \cdot \mathrm{m}^{-2}$ and $\mathrm{kg} \cdot \mathrm{ha}^{-1}$ between cycles (2018-2019/2019-2020) and between treatments, highlighting the QUI 100\% + IBA $0.937 \mathrm{~kg} \cdot \mathrm{ha}^{-1}$ with a production of $671.3 \mathrm{~kg} \cdot \mathrm{ha}^{-1} ; 350 \%$ higher compared to the control treatment $\left(191.1 \mathrm{~kg} \cdot \mathrm{ha}^{-1}\right)$; the analyzes at the level of year $\times$ treatments, the values were not shown to be significant.

Table 6. Yield and production of biomass (dry matter $\mathrm{g} \cdot \mathrm{m}^{-2}$ ) and effect on the content of lipids, proteins, humidity and ash of the seed of S. bigelovii, produced by cuttings under conditions of the Altar desert, Sonora.

\begin{tabular}{|c|c|c|c|c|c|c|c|c|}
\hline \multirow[b]{2}{*}{ Treatments } & \multicolumn{2}{|c|}{ Seed Production (g) } & \multicolumn{6}{|c|}{ Seed } \\
\hline & g. plant ${ }^{-1}$ & $\mathrm{~g} \cdot \mathrm{m}^{-2}$ & $\mathrm{~kg} \cdot \mathrm{ha} \mathrm{a}^{-1}$ & $\begin{array}{c}\text { Dry Matter } \\
\mathrm{g} \cdot \mathrm{m}^{-2}\end{array}$ & $\begin{array}{l}\text { Ash } \\
(\%)\end{array}$ & $\begin{array}{l}\text { Proteins } \\
(\%)\end{array}$ & $\begin{array}{c}\text { Humidity } \\
(\%)\end{array}$ & $\begin{array}{l}\text { Lipids } \\
\text { (mg/g) }\end{array}$ \\
\hline QUI 50\% & $1.30 \pm 0.09 \mathrm{~b}$ & $51.1 \pm 4.1 \mathrm{~b}$ & $511.0 \pm 4.1 \mathrm{~b}$ & $1495 \pm 146 \mathrm{bc}$ & $18.6 \pm 1.1 \mathrm{~b}$ & $21.1 \pm 1.9 \mathrm{~b}$ & $4.6 \pm 0.1 \mathrm{~b}$ & $89.0 \pm 3.3 \mathrm{ab}$ \\
\hline QUI 100\% & $1.52 \pm 0.09 a$ & $64.2 \pm 3.9 \mathrm{a}$ & $642.2 \pm 3.9 \mathrm{a}$ & $1799 \pm 202 b$ & $22.5 \pm 1.1 \mathrm{a}$ & $20.1 \pm 1.9 b c$ & $4.6 \pm 0.3 \mathrm{~b}$ & $89.7 \pm 3.1 \mathrm{ab}$ \\
\hline QUI $0.937 \mathrm{~g} \cdot \mathrm{kg}^{-1}$ & $0.55 \pm 0.04 \mathrm{~d}$ & $21.0 \pm 8.8 \mathrm{c}$ & $210.8 \pm 8.8 \mathrm{c}$ & $1582 \pm 162 \mathrm{bc}$ & $18.1 \pm 1.3 \mathrm{~b}$ & 21. $\pm 1.98 \mathrm{~b}$ & $4.1 \pm 0.4 \mathrm{~b}$ & $86.1 \pm 2.1 \mathrm{~b}$ \\
\hline QUI $1.25 \mathrm{~g} \cdot \mathrm{kg}^{-1}$ & $1.53 \pm 0.10 \mathrm{a}$ & $60.0 \pm 6.3 \mathrm{a}$ & $600.3 \pm 6.3 \mathrm{a}$ & $1497 \pm 276 b c$ & $23.4 \pm 1.4 \mathrm{a}$ & $22.0 \pm 1.9 \mathrm{~b}$ & $4.5 \pm 0.9 \mathrm{a}$ & $83.4 \pm 2.2 \mathrm{c}$ \\
\hline QUI $50 \%+$ IBA $0.937 \mathrm{~g} \cdot \mathrm{kg}^{-1}$ & $1.55 \pm 0.09 \mathrm{a}$ & $65.0 \pm 6.1 \mathrm{a}$ & $650.9 \pm 6.1 \mathrm{a}$ & $1775 \pm 123 \mathrm{~b}$ & $22.5 \pm 1.0 \mathrm{a}$ & $24.6 \pm 0.9 \mathrm{a}$ & $4.0 \pm 0.9 \mathrm{~b}$ & $95.1 \pm 4.9 \mathrm{a}$ \\
\hline QUI $50 \%+$ IBA $1.25 \mathrm{~g} \cdot \mathrm{kg}^{-1}$ & $1.34 \pm 0.8 \mathrm{~b}$ & $55.0 \pm 3.9 \mathrm{~b}$ & $550.2 \pm 3.9 \mathrm{~b}$ & $1512 \pm 215 \mathrm{bc}$ & $21.6 \pm 1.3 \mathrm{a}$ & $23.6 \pm 0.9 \mathrm{ab}$ & $4.2 \pm 0.2 \mathrm{~b}$ & $94.4 \pm 4.1 \mathrm{a}$ \\
\hline QUI $100 \%$ + IBA $0.937 \mathrm{~g} \cdot \mathrm{kg}^{-1}$ & $1.56 \pm 0.11 \mathrm{a}$ & $67.1 \pm 7.1 \mathrm{a}$ & $671.3 \pm 7.1 \mathrm{a}$ & $2213 \pm 189 a$ & $14.3 \pm 1.1 \mathrm{c}$ & $25.9 \pm 1.3 \mathrm{a}$ & $4.9 \pm 0.2 \mathrm{ab}$ & $93.1 \pm 3.9 \mathrm{a}$ \\
\hline QUI $100 \%+$ IBA $1.25 \mathrm{~g} \cdot \mathrm{kg}^{-1}$ & $1.02 \pm 0.07 c$ & $23.0 \pm 9.9 c$ & $230.9 \pm 9.9 c$ & $2098 \pm 119 a$ & $12.1 \pm 0.3 \mathrm{~d}$ & $21.4 \pm 0.2 \mathrm{~b}$ & $4.3 \pm 0.5 b$ & $88.0 \pm 1.4 \mathrm{ab}$ \\
\hline Control & $0.54 \pm 0.11 \mathrm{~d}$ & $19.1 \pm 10.9 \mathrm{c}$ & $191.1 \pm 10.9 \mathrm{c}$ & $1441 \pm 129 c$ & $21.12 \pm 0.9 b$ & $19.0 \pm 0.3 c$ & $4.7 \pm 0.3 \mathrm{~b}$ & $92.2 \pm 2.7 \mathrm{a}$ \\
\hline
\end{tabular}

Means with equal letters within each column are not differences statistically $(p>0.05)$. QUI $=$ Chitosan.

Regarding biomass production $\left(\mathrm{g} \cdot \mathrm{m}^{-2}\right)$, the treatments that showed higher and significant values were QUI $100 \%$ + IBA 0.937 and $0.125 \mathrm{~g} \cdot \mathrm{kg}^{-1}$, with 2213 and $2098 \mathrm{~g} \cdot \mathrm{m}^{-2}$, respectively; however, these values were similar between vegetative cycles $(p<0.05)$, surpassing the less productive treatment $\left(1.441 \mathrm{~g} \cdot \mathrm{m}^{-2}\right.$ for the control), by $53 \%$; in the interaction cycle $\times$ treatments there were no differences.

\subsection{Ash, Protein, and Lipid Ratios of the S. bigelovii Seed}

The results obtained in analysis of ash, moisture and protein, showed significant differences between treatments with the exception of lipid content; it was observed that between productive cycles the values behaved in a similar way as well as in the interaction cycle $\times$ treatments. In Table 6, it can be seen that, in the content of seed protein, the QUI at 50 and $100 \%+$ IBA $0.937 \mathrm{~g} \cdot \mathrm{kg}^{-1}$ were the outstanding ones with $p<0.05(24.60$ and $25.91 \%$, respectively), in comparison of the other treatments; on the other hand, the witness is the one who throws the lowest values.

Regarding lipid content, there were no significant differences between treatments, except for the IBA $1.25 \mathrm{~g} \cdot \mathrm{kg}^{-1}$, which was the one that showed the lowest values $(83.42 \mathrm{mg} \cdot \mathrm{g})$, while the QUI at 50\% + IBA $0.937(95.16 \mathrm{mg} \cdot \mathrm{g})$ was the one that yielded the highest. In moisture and ash, the behavior was opposite to those obtained in protein and lipids, the IBA $1.25 \mathrm{~g} \cdot \mathrm{kg}^{-1}$, was the treatment that obtained the highest values compared to the others (Table 6).

\subsection{Lipid Profile of S. bigelovii Seed}

Based on the proportions of fatty acids (Table 7), statistical analyzes indicate significant differences $(p>0.05)$ between treatments. It can be seen that QUI $50 \%+$ IBA $0.937 \mathrm{~g} \cdot \mathrm{kg}^{-1}$, is the one that significantly influences in two fatty acids: palmitic and stearic. The contrary

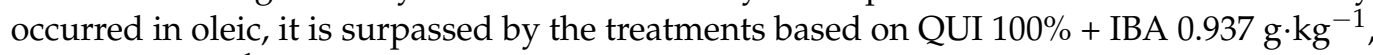
IBA $1.25 \mathrm{~g} \cdot \mathrm{kg}^{-1}$ and QUI $100 \%$. Although the control in these three fatty acids be haved with the lowest values, for the case of linoleic and linolenic it turned out to be the highest values (Table 7). No significant values were found between the production cycles and their interaction cycle treatments. 
Table 7. Effect of the application of Chitosan (QUI) and Indole Butyric Acid (IBA) on the profile of fatty acids (palmitic, stearic, oleic, linoleic and linolenic) in the seed of S. bigelovii plants and life cycle (in days) under conditions of the Altar desert, Sonora.

\begin{tabular}{|c|c|c|c|c|c|c|}
\hline Treatments & Palmitic & Stearic & $\begin{array}{c}\text { Fatty Acids (\%) } \\
\text { Oleic }\end{array}$ & Linoleic & Linolenic & Life Time * \\
\hline QUI 50\% & $11.51 \pm 1.3 c$ & $1.87 \pm 0.10 b$ & $14.85 \pm 0.31 \mathrm{ab}$ & $66.55 \pm 1.39 b$ & $2.32 \pm 0.69 \mathrm{a}$ & $233 \pm 10 \mathrm{ab}$ \\
\hline QUI 100\% & $10.36 \pm 1.1 \mathrm{c}$ & $1.62 \pm 0.12 c$ & $13.24 \pm 1.53 \mathrm{~b}$ & $67.00 \pm 1.13 b$ & $2.58 \pm 0.25 \mathrm{a}$ & $227 \pm 10 b$ \\
\hline IBA $0.937 \mathrm{~g} \cdot \mathrm{kg}^{-1}$ & $10.61 \pm 1.1 \mathrm{c}$ & $1.21 \pm 0.40 \mathrm{c}$ & $13.18 \pm 1.69 \mathrm{~b}$ & $67.00 \pm 1.09 \mathrm{a}$ & $2.55 \pm 0.29 \mathrm{a}$ & $221 \pm 9 b$ \\
\hline IBA $1.25 \mathrm{~g} \cdot \mathrm{kg}^{-1}$ & $14.26 \pm 0.7 \mathrm{ab}$ & $1.00 \pm 0.41 \mathrm{c}$ & $14.14 \pm 0.32 \mathrm{ab}$ & $67.00 \pm 0.94 b$ & $2.50 \pm 0.37 \mathrm{a}$ & $220 \pm 8 b$ \\
\hline QUI $50 \%$ + IBA $0.937 \mathrm{~g} \cdot \mathrm{kg}^{-1}$ & $15.67 \pm 0.9 \mathrm{a}$ & $2.11 \pm 0.12 \mathrm{a}$ & $13.18 \pm 0.39 b$ & $66.65 \pm 1.54 b$ & $2.49 \pm 0.41 b$ & $244 \pm 9 \mathrm{a}$ \\
\hline QUI 50\% + IBA $1.25 \mathrm{~g} \cdot \mathrm{kg}^{-1}$ & $12.76 \pm 0.4 \mathrm{bc}$ & $1.99 \pm 0.13 b$ & $13.87 \pm 0.69 b$ & $68.55 \pm 1.11 b$ & $2.83 \pm 0.28 \mathrm{a}$ & $249 \pm 7 a$ \\
\hline QUI $100 \%$ + IBA $0.937 \mathrm{~g} \cdot \mathrm{kg}^{-1}$ & $13.71 \pm 0.3 \mathrm{~b}$ & $1.09 \pm 0.33 c$ & $15.21 \pm 1.07 \mathrm{a}$ & $67.98 \pm 1.34 b$ & $2.01 \pm 0.53 \mathrm{a}$ & $251 \pm 9 a$ \\
\hline QUI $100 \%+$ IBA $1.25 \mathrm{~g} \cdot \mathrm{kg}^{-1}$ & $15.46 \pm 0.9 \mathrm{a}$ & $1.11 \pm 0.22 c$ & $12.98 \pm 0.39 c$ & $68.32 \pm 1.03 \mathrm{~b}$ & $2.13 \pm 0.59 \mathrm{a}$ & $254 \pm 10 a$ \\
\hline Control & $9.58 \pm 1.9 c$ & $1.44 \pm 0.20 c$ & $13.90 \pm 0.11 c$ & $72.09 \pm 0.78 \mathrm{a}$ & $2.99 \pm 0.56 \mathrm{a}$ & $188 \pm 1.9 c$ \\
\hline
\end{tabular}

Means with equal letters within each column are not differences statistically $(p>0.05)$. ${ }^{*}$ Life time (days).

\subsection{Chitosan and IBA Life Period in S. bigelovii}

Regarding the life period (planting of cuttings until seed production), due to the effect of Chitosan and IBA in the cuttings of S. bigelovii, the results obtained in Table 7 indicate that the control (fresh water without QUI and IBA) lasted for less time (188 dat until physiological maturity (seed production)), compared with other treatments analyzed $(p<0.05)$, with the life cycle of the plants oscillating from 220 to 254 dat. The longest treatment was based on QUI $100 \%+$ IBA $1.25 \mathrm{~g} \cdot \mathrm{kg}^{-1}$. No significant difference was found between cycles and cycle $\times$ treatments.

\section{Discussion}

The yield obtained for the chitosan extraction process in the present study could be compared with authors such as Hernández Cocoletzi et al. [21], De la Paz et al. [30] and Vargas and Taquez [31], who obtained similar yields, who have considered this extraction process as an effective method where a percentage of obtaining can be obtained with an efficient synthetic transformation [22]. It has been reported that some of the factors that influence chitosan yields are: raw material, method used, temperature, reaction time and concentration of solvents [21,32]. Therefore, the method used in the present study can be considered optimal for the effective obtaining of chitosan from marine sources. Likewise, it has been reported that chitin and chitosan yields vary among species, being higher in crab and shrimp [21]. Chitosan generally represents about $70 \%$ of the chitin of the species [32,33]. Moreover, different conditions to obtain chitosan could modify the molecular weight of chitosan obtained is $6.22 \times 10^{5} \pm 5 \times 10^{3} \mathrm{~g} \cdot \mathrm{mol}$ [21]

In the present study, the results showed that those treatments with chitosan and IBA, separately or in synergy, were those that had a positive effect on an increase in seed production compared to the control treatment. Studies related to IBA show that it is frequently used for the propagation of cuttings or cuttings and layers; This type of growth hormones has shown a positive effect on the development of plants (mainly woody ones), by stimulating the formation of lateral roots [34], an effect that was visualized in the present study; It could also be seen that the IBA individually, when used above $1000 \mathrm{~g} \mathrm{~kg}^{-1}$, in S. bigelovii offers significant results compared to the control and in contrast to those found by Dias et al. [23] indicates that in concentrations above $1000 \mathrm{mg} \mathrm{kg}^{-1}$ they can affect the proper development of plants to a certain degree, in addition to revealing that IBA at high doses can be harmful to the plant.

On the other hand, the biostimulant effect by chitosan on seeds has been studied by [24]. With the results obtained in the present study, the efficacy of chitosan (rooting, seed production, lipid quality and biomass) was increased using IBA, which suggests the synergy between both compounds. Although the investigations on chitosan in halophytes are null, several studies carried out by other authors [13,24,35], using chitosan in different crops (rice, cucumber, cereals and fruit trees), summarize the beneficial effects of the 
biopolymer on the production variable. Our results coincide with what was previously revealed, since the participation of chitosan and IBA (in their individual form or in a mixture), influenced the generation of roots (Table 3), an advantage that, in the subsequent phenological stages, had a positive impact according to the variables evaluated in the present study. Some works have reported a biomass yield of S. bigelovii around 1.7$2.46 \mathrm{t} / \mathrm{ha}$ [36] and of $430 \pm 220 \mathrm{~kg} / \mathrm{ha}$ of seed [37]; With the results obtained in the present investigation, the association between chitosan and IBA, promise results above $2000 \mathrm{~kg} / \mathrm{ha}$, competent values in forage production and rich in protein $(>14 \%)$, such as alfalfa (queen of forage crops) which makes it a prospective plant for multiple industries. Biostimulants such as chitosan contain active principles, which act on the physiology and development of plants, improving their productivity and performance [36], which led to obtaining beneficial effects from this biopolymer in synergy with IBA, on the halophyte S. bigelovii.

In the present work, the experimental conditions in which it was developed (Table 2), do not show a contrast in the edaphoclimatic factors (Tables 2 and 3), however it can be seen that although the second vegetative cycle developed with a month of anticipation compared to the first, weather conditions influence the variables (root length, fresh and dry root weight, number and length of shoots, seed production g.plant ${ }^{-1}, \mathrm{~g} \cdot \mathrm{m}^{-2}$ and $\mathrm{kg} \cdot \mathrm{ha}^{-1}$, ash, moisture and protein in addition to the profile of fatty acids in seed; the opposite occurred in nitrates, biomass $\left(\mathrm{g} \cdot \mathrm{m}^{-2}\right)$, total lipids in seed and life time). It can be seen in Table 3 that the properties of the soil in the experiment had the same conditions in the two vegetative cycles, which together with the environment $\left(\mathrm{T}^{\circ}, \mathrm{RH}, \mathrm{Par}\right.$ and Aai $=$ Table 2) generated a favorable atmosphere that managed to reach harvest yields, since factors typical of the crop soil, density and spacing of the stakes and spacing between them, are adequate, otherwise factors such as a water deficiency, can significantly reduce the aerial biomass, harvest index, weight or seed size and seed yield. It could be recommended to carry out additional studies, lagging the transplantation of cuttings in totally different months (to the present study) in temperature and relative humidity (considering seasons of the year) including variability in the type of soil, to know the effect of these conditions on the variables studied in the present study.

It has been mentioned that the productivity in some crops depends on the relationships of complementation and competition between the species and the components of the agrosystem. In Salicornia the productivity of this halophyte has been related to the availability of nitrogen in the biomass, in those cases where there is nitrogen deficiency, different types of fertilizers have been used, some of them of natural origin and other chemicals, the latter not so beneficial. For the environment. In the case of chitosan in synergy with the IBA, when observing in the current work high productions of seed and biomass, they invite to hypothesize about a better use of solar radiation, nitrogen, water and nutrients present in the development. However, it is advisable to use sources rich in N, $\mathrm{P}$ and K. It has been reported that seeds that are treated with chitosan show better characteristics $[38,39]$, this thanks to the beneficial effects of chitosan in the synthesis, degradation and translocation of fat and carbohydrate biomolecules [40-42], in addition to actively influencing the defense response of the plant, the release of nutrients and protecting from microbial damage [43-46]. Likewise, in recent studies, the content of protein, fiber and total ash has been reported for Salicornia between $30-40 \%, 4.5-8 \%$ and $5.5-8.5 \%$ respectively [6], and although in the present study was not analyzed in green matter, these variables can highlight Salicornia in the formulation of food for shrimp and fish, due to the high content of protein and fiber, an aspect that makes it comparable to other flours such as wheat [22].

Based on lipid studies in seeds in S. bigelovii, there are those in plants inoculated with bacteria that promote plant growth and fixation of $\mathrm{N}_{2}$, obtaining higher values of lipids, proteins, ash and humidity compared to those plants that are not inoculated [1]. These results agree with those obtained in the present work, to use Chitosan-IBA as a nutritional source. In the present study, the agronomic characteristics of Salicornia are improved when treated with chitosan, which is an environmentally friendly biopolymer that can be implemented in different crops and agricultural techniques, to improve their yields 
and development characteristics, helping largely to agricultural production [6]. The high content of lipids of halophyte allows it to be considered for the cosmetology and biofuel industry, in the latter, it can comply with the three principles of second generation biofuels: it does not use food for humans or animals, it is not produced on land for cultivation and does not use water for irrigation or human consumption. For S. bigelovii, a content of saturated and unsaturated fatty acids of $15.8 \%$ and $83.9 \%$ respectively has been reported, being predominant in the latter with linoleic and oleic acid with values of $69.5-75 \%$ and $12-14.5 \%$ respectively [1]. In addition to being rich in these acids, especially linoleic acid, it also contains palmitic acid and lower levels of stearic and $\alpha$-linolenic acid that range in values of $7.52-8.7 \%, 1.45-2.4 \%$ and $2.4-2.7$ correspondingly [1].

During all the phenological stages of $S$. bigelovii, chitosan remained actively, managing to provide the plant with the necessary protection for its optimal development. In addition to this, the polymer structure is composed of two N-acetyl-D-glucosamine and D-glucosamine units [24], which present about $7 \%$ Nitrogen $[27,47]$ that during the development stages of the halophyte could be exploited in a beneficial way. Likewise, the irrigation system that was used (micro-sprinkling) in the present study, allows the chitosan not to be easily detached from the rooted rod of the plant, that is, since it is not a flood irrigation, the system only moistens the plant without a wash.

Finally, it should be noted that the plants treated with Chitosan-IBA presented longer phenological stages, compared to the control. This is due to the fact that the plants not treated as the control do not have enough nutrient available, therefore, the life cycle is shortened. In this sense, when conditions are favorable and there is the presence of necessary nutrients in the plants, as is the case with those treated with Chitosan and IBA, these probably influence the speed of metabolism and the cell cycle of halophyte, delaying the phenological stages, which is reflected in more vigorous plants and better yields. Chitosan is a compound that has a wide range of applications thanks to its biological properties: antimicrobial, antioxidant, anti-inflammatory, antifungal, among others $[45,48$, 49]. Although the mechanisms of action of chitosan have not yet been elucidated in detail, its multiple benefits can be exploited in the optimal development of crops of agronomic interest, as is the case of S. bigelovii in Northwest Mexico.

\section{Conclusions}

Currently, sustainable sources are being sought in agriculture, in order to displace the chemicals used and improve yields. In the present study, chitosan in synergy with IBA, positively influenced the vegetative development and seed yields of S. bigelovii. UNder the field conditions established in the two vegetative cycles, Chitosan-IBA increased the lipid proportion of the seeds compared to the control used. For S. bigelovii, a high content of saturated and unsaturated fatty acids has been reported, which showed an increase under the treatments based on Chitosan-IBA, compared to the control. In addition to this, significant differences were found for the variables of dry biomass and seed production, due to the biostimulant effect of the biopolymer and IBA. During all the phenological stages of the halophyte, the chitosan remained in an active way, managing to provide the plant with the nutrients and protection necessary for its optimal development. The yields obtained for S. bigelovii indicate that high productions can be obtained, which makes it a prospective plant for multiple industries, including biofuels and cosmetology, thanks to the high lipid content of its seed.

Author Contributions: Conceptualization, P.P.-R., E.O.R.-P. and G.Z.-S.; methodology, G.Z.-S., R.J.H.P. and C.B.-M.; software, P.P.-R.; validation, G.Z.-S., E.O.R.-P. and P.P.-R.; formal analysis, P.P.-R., E.O.R.-P. and G.Z.-S.; investigation, E.O.R.-P., R.R.G.-E., R.J.H.-P. and C.B.-M.; data curation and analysis, P.P.-R., E.O.R.-P. and F.S.B.; writing-original draft preparation, E.O.R.-P., P.P.-R., G.Z.-S. and R.R.G.-E.; writing - review and editing, E.O.R.-P.; visualization, E.O.R.-P.; supervision, E.O.R.-P. All authors have read and agreed to the published version of the manuscript.

Funding: This research received no external funding. 


\section{Data Availability Statement: Not applicable.}

Acknowledgments: The authors would like to extend their gratitude to the National Technological Institute of Mexico, Campus Instituto Tecnológico de Torreón, for allowing us to use their facilities. The authors are also grateful for the technical assistance of the Water and Soil Analysis Laboratory technicians of UAAAN.

Conflicts of Interest: The authors declare no conflict of interest of any kind; the funders had no role in the design and implementation of this research and its data interpretation, nor in the decision to write and submit this manuscript.

\section{References}

1. Beltrán, B.; Bianciotto, O.; López-Ahumada, G.; Vargas, J.; Hernández-Montiel, L.G.; Reyes-Pérez, J.; Nieto-Garibay, A.; RuizEspinoza, F.; Alvarez, A.; Rueda-Puente, E.O.; et al. Salicornia bigelovii (Torr.): Un sistema modelo para incorporarse como cultivo agrícola en zonas árido-desérticos. Biotecnia 2017, XIX, 46-50. [CrossRef]

2. Christiansen, A.H.C.; Lyra, D.A.; Jørgensen, H. Increasing the value of Salicornia bigelovii green biomass grown in a desert environment through biorefining. Ind. Crop. Prod. 2021, 160, 113105. [CrossRef]

3. Joshi, A.; Arora, J.; Kanthaliya, B. Halophytes: The Nonconventional Crops as Source of Biofuel Production. In Handbook of Halophytes; Springer: Berlin/Heidelberg, Germany, 2020; pp. 1-28. [CrossRef]

4. El-Araby, R.; Rezk, A.I.; El-Enin, S.A.A.; Nofal, O.A.; El-Nasharty, A.B. Comparative evaluation of Salicornia bigelovii oil planted under different treatments. Bull. Natl. Res. Cent. 2020, 44, 133. [CrossRef]

5. Farooq, A.; Bhanger, M.; Khalil, M.; Nasir, A.; Sarwat, I. Analytical Characterization of Salicornia bigelovii Seed Oil Cultivated in Pakistan. J. Agric. Food Chem. 2002, 50, 4210-4214. [CrossRef]

6. López-Corona, B.E.; Mondaca-Fernández, I.; Gortáres-Moroyoqui, P.; Meza-Montenegro, M.M.; Balderas-Cortés, J.d.J.; RuizAlvarado, C.; Rueda-Puente, E.O. Enraizamiento de esquejes de Salicornia bigelovii (Torr.) por quitosano como un bioproducto de origen marino. Terra Latinoam. 2019, 37,361-369. [CrossRef]

7. Bhaskara Reddy, M.V.; Arul, J.; Angers, P.; Couture, L. Chitosan Treatment of Wheat Seeds Induces Resistance to Fusarium graminearum and Improves Seed Quality. J. Agric. Food Chem. 1999, 47, 1208-1216. [CrossRef] [PubMed]

8. Kim, M.-W.; Han, Y.; Jo, Y.H.; Choi, M.; Kang, S.; Kim, S.-A.; Jung, W.-J. Extraction of chitin and chitosan from housefly, Musca domestica, pupa shells: Production of chitin from housefly. Entomol. Res. 2016, 46. [CrossRef]

9. Beaney, P.; Lizardi-Mendoza, J.; Healy, M. Comparison of chitins produced by chemical and bioprocessing methods. J. Chem. Technol. Biotechnol. 2005, 80, 145-150. [CrossRef]

10. Kumari, S.; Rath, P.; Sri Hari Kumar, A.; Tiwari, T.N. Extraction and characterization of chitin and chitosan from fishery waste by chemical method. Environ. Technol. Innov. 2015, 3, 77-85. [CrossRef]

11. Younes, I.; Rinaudo, M. Chitin and chitosan preparation from marine sources. Structure, properties and applications. Mar. Drugs 2015, 13, 1133-1174. [CrossRef]

12. Si Trung, T.; Bao, H.N.D. Physicochemical Properties and Antioxidant Activity of Chitin and Chitosan Prepared from Pacific White Shrimp Waste. Int. J. Carbohydr. Chem. 2015, 2015, 706259. [CrossRef]

13. Rasti, H.; Parivar, K.; Baharara, J.; Iranshahi, M.; Namvar, F. Chitin from the Mollusc Chiton: Extraction, Characterization and Chitosan Preparation. Iran. J. Pharm. Res. 2017, 16, 366-379.

14. Ren, L.; Yan, X.; Zhou, J.; Tong, J.; Su, X. Influence of chitosan concentration on mechanical and barrier properties of corn starch/chitosan films. Int. J. Biol. Macromol. 2017, 105, 1636-1643. [CrossRef] [PubMed]

15. Gómez, L.; Nápoles García, M.; Arteaga, J.; Cruz, L.; Martínez, I.; Falcón, A.; Aguilera, L. Evaluación de la aplicación de quitosana sobre plántulas de tabaco (Nicotiana tabacum L.) Evaluation of the application of chitosan on tobacco seedlings (Nicotiana tabacum L.). Centro Agrícola 2017, 44, 34-40.

16. Sansano, M.; Heredia, A.; Glicerina, V.; Balestra, F.; Romani, S.; Andrés, A. Influence of chitosan on thermal, microstructural and rheological properties of rice and wheat flours-based batters. LWT 2018, 87, 529-536. [CrossRef]

17. Pitoyo, A.; Hani, R.; Anggarwulan, E. Application of chitosan spraying on acclimatization success of tiger orchid (Grammatophyllum scriptum) plantlets. Nusant. Biosci. 2015, 7, 179-185. [CrossRef]

18. Rahman, M.; Mukta, J.A.; Sabir, A.A.; Gupta, D.R.; Mohi-Ud-Din, M.; Hasanuzzaman, M.; Miah, M.G.; Rahman, M.; Islam, M.T. Chitosan biopolymer promotes yield and stimulates accumulation of antioxidants in strawberry fruit. PLoS ONE 2018, 13, e0203769. [CrossRef]

19. Mehebub, M.; Mahmud, N.; Rahman, M.; Surovy, M.; Gupta, D.; Hasanuzzaman, M.; Rahman, M.; Islam, T. Chitosan biopolymer improves the fruit quality of litchi (Litchi chinensis Sonn.). Acta Agrobotica 2019, 72. [CrossRef]

20. Hernández Cocoletzi, H.; Águila Almanza, E.; Flores Agustin, O.; Viveros Nava, E.L.; Ramos Cassellis, E. Obtención y caracterización de quitosano a partir de exoesqueletos de camarón. Superf. Vacío 2009, 22, 57-60.

21. Arenas, N.; Pinilla Plata, A.; Henao Martínez, J.A. Arcilla bentonítica modificada con quitosano para materiales compuestos biodegradables. Dyna 2011, 78, 59-65.

22. Dias, J.P.T.; Ono, E.O.; Duarte Filho, J. Enraizamento de estacas de brotações oriundas de estacas radiculares de amoreira-preta1. Rev. Bras. Frutic. 2011, 33, 649-653. [CrossRef] 
23. Ramírez Arrebato, M.; Rodriguez Pedroso, A.; Alfonso, L.; Peniche, C. Chitin and its derivatives as biopolymers with potential agricultural applications. Biotecnol. Apl. 2010, 27, 270-276.

24. Ruiz, G.R.; Vargas, H.J.; Cetina, A.V.; Villegas, M. Effect of indol-butiric acid (iba) and type of cutting on rooting of Gmelina arborea Roxb. Rev. Fitotec. Mex. 2005, 28, 319-326.

25. Coombs, J.; May, S.; Long, D.; Scurlock, J. Técnicas en Fotosintesis y Bioproductividad; Asociación de Postgraduados: Chapingo, Mexico, 1988; pp. 1-204.

26. Wood, E. Determination of nitrate in sea water by cadmium cooper reduction to nitrite. J. Mar. Biol. Assoc. U. K. 1967, 47, 23-31. [CrossRef]

27. Kumar, M.N.V. A review of chitin and chitosan applications. React. Funct. Polym. 2000, 46, 1-27. [CrossRef]

28. Arredondo, V.; Cordero, E.; Herrero, C.; Abalde, J. Manual de Técnicas Bioquímicas Aplicadas en Ficología; Centro de Investigación Científica y Estudios Superiores de Ensenada, Centro de Investigaciones Biológicas del Noroeste y Universidad de Coruña: La Paz, Baja California Sur, Mexico, 1997; p. 70.

29. Sato, N.; Murata, N. Membrane lipids. In Methods in Enzymology; Academic Press: Cambridge, MA, USA, 1988; Volume 167, pp. 251-259.

30. De la Paz, N.; Fernández, M.; López, O.; Nogueira, A.; García, C.; Pérez, D.; Díaz, D. Optimización del proceso de obtención de quitosana derivada de quitina de langosta. Rev. Iberoam. Polímeros 2002, 13, 103-116.

31. Vargas-Torres, G.; Taquez-Bueno, L. Obtención y Evaluación del Quitosano a Nivel Laboratorio para la Depuración de Aguas Residuales Industriales Provenientes de un Laboratorio Cosmético. Available online: https://repository.unad.edu.co/bitstream/ handle/10596/18323/53094495.pdf? sequence=1\&isAllowed=y (accessed on 21 January 2021).

32. Varamin, J.; Fanoodi, F.; Sinaki, J.M.; Rezvan, S.; Damavandi, A. Foliar application of chitosan and nano-magnesium fertilizers influence on seed yield, oil content, photosynthetic pigments, antioxidant enzyme activities of sesame (Sesamum indicum L.) under water-limited conditions. Not. Bot. Horti Agrobot. Cluj Napoca 2020, 48, 2228-2243. [CrossRef]

33. Mármol, Z.; Gutiérrez, E.; Páez, G.; Ferrer, J.; Rincón, M. Desacetilación termoalcalina de quitina de conchas de camarón. Multiciencias 2004, 4, 123-134.

34. Báez-Pérez, A.; González-Molina, L.; Solís Moya, E.; Bautista-Cruz, A.; Bernal-Alarcón, M.d.l.Á. Efecto de la aplicación del ácido indol-3-butiríco en la producción y calidad de trigo (Triticum aestivum L.). Rev. Mex. Cienc. Agrícolas 2015, 6, 523-537. [CrossRef]

35. Zerpa, J.; Marinela, C.; Rincón, D.; Colina, J. Efecto del uso de quitosano en el mejoramiento del cultivo del arroz (Oryza sativa L. variedad sd20a). Rev. Investig. Agrar. Ambient. 2017, 8, 151-165. [CrossRef]

36. Jiménez, N.; Jiménez, M.; Falcón, A.; Gonzáles, G.; Silvente, J. Evaluación de tres dosis de quitosano en el cultivo de pepino en un periodo tardío. Rev. Electrón. Cienc. Granma 2009, 13, 1-6.

37. Mota Urbina, C. Revista Claridades Agropecuarias. Available online: https://info.aserca.gob.mx/claridades/revistas/003/ca003 .pdf\#page $=24$ (accessed on 14 January 2021).

38. Hadwiger, L.A.; Fristensky, B.; Riggleman, R.C. Chitosan, a natural regulator in plant-fungal pathogen interactions, increases crop yields. In Chitin, Chitosan, and Related Enzymes; Zikakis, J.P., Ed.; Academic Press: Cambridge, MA, USA, 1984; pp. $291-302$. [CrossRef]

39. Guan, Y.-J.; Hu, J.; Wang, X.-J.; Shao, C.-X. Seed priming with chitosan improves maize germination and seedling growth in relation to physiological changes under low temperature stress. J. Zhejiang Univ. Sci. B 2009, 10, 427-433. [CrossRef]

40. Ngo, D.-H.; Vo, T.-S.; Ngo, D.-N.; Kang, K.-H.; Je, J.-Y.; Pham, H.N.-D.; Byun, H.-G.; Kim, S.-K. Biological effects of chitosan and its derivatives. Food Hydrocoll. 2015, 51, 200-216. [CrossRef]

41. Sarkar, S.; Das, D.; Dutta, P.; Kalita, J.; Wann, S.B.; Manna, P. Chitosan: A promising therapeutic agent and effective drug delivery system in managing diabetes mellitus. Carbohydr. Polym. 2020, 247, 116594. [CrossRef]

42. Hadwiger, L.A. Multiple effects of chitosan on plant systems: Solid science or hype. Plant Sci. Int. J. Exp. Plant Biol. 2013, 208, 42-49. [CrossRef] [PubMed]

43. López, M.; Ruiz-Cruz, S.; Navarro-Preciado, C.; Ornelas-Paz, J.; Estrada, M.; Gassos-Ortega, L.; Rodrigo-Garcia, J. Efecto de recubrimientos comestibles de quitosano en la reducción microbiana y conservación de la calidad de fresas. Biotecnia 2012, 14, 33. [CrossRef]

44. Cheah, L.H.; Page, B.B.C.; Shepherd, R. Chitosan coating for inhibition of sclerotinia rot of carrots. N. Z. J. Crop Hortic. Sci. 1997, 25, 89-92. [CrossRef]

45. Liu, J.; Tian, S.; Meng, X.; Xu, Y. Effects of chitosan on control of postharvest diseases and physiological responses of tomato fruit. Postharvest Biol. Technol. 2007, 44, 300-306. [CrossRef]

46. Chakraborty, M.; Hasanuzzaman, M.; Rahman, M.; Khan, M.; Bhowmik, P.; Mahmud, N.; Tanveer, M.; Islam, T. Mechanism of Plant Growth Promotion and Disease Suppression by Chitosan Biopolymer. Agriculture 2020, 10, 624. [CrossRef]

47. Muzzarelli, R.A.A. Chapter 1-Enzymic synthesis of chitin and chitosan. In Chitin; Muzzarelli, R.A.A., Ed.; Pergamon: Oxford, UK, 1977; pp. 5-44. [CrossRef]

48. Devlieghere, F.; Vermeulen, A.; Debevere, J. Chitosan: Antimicrobial activity, interactions with food components and applicability as a coating on fruit and vegetables. Food Microbiol. 2004, 21, 703-714. [CrossRef]

49. Hewajulige, I.; Sultanbawa, Y.; Wijeratnam, S.; Wijesundara, R. Mode of action of chitosan coating on anthracnose disease control in papaya. Phytoparasitica 2009, 37, 437-444. [CrossRef] 